\title{
Profile of Stunted Children in Cameroon, A Mics 2014 Analyses
}

\author{
Article by Eveline Ngwenyi ${ }^{1}$, Eric Gyamfi ${ }^{2}$ \\ ${ }^{1}$ Texila American University, South America, Guyana \\ ${ }^{2}$ Withrow University College, Agona Asamang, Ghana \\ Email:fondeeve@yahoo.fr ${ }^{1}$,gyamfieric2008@yahoo.com ${ }^{2}$
}

\begin{abstract}
Background: Under Nutrition Is One of World's Most Serious but Least Addressed Health Problems. Malnutrition Is Widespread In Cameroon Especially In The Northern Regions Of Cameroon. There Are Currently Very Little Or No Data On Factors Associated With Stunting In Cameroon. This Paper Presents Some Factors Associated With Stunting In Adamaoua, East, Far North And North Regions Of Cameroon.

Method: This Study Analysed Dataset Of The Firth Round Of Cameroon Multiple Indicator Cluster Survey (MICS5) To Establish Risk Factors Associated With Stunting In Four Regions Of Cameroon

Results: 3085 Cases were Analysed, with stunting Prevalence Rates Of 31.7\% At National Level, 37.8\%, 35.8\% , 41.9\% And 33.8\% Respectively In Adamaoua, East, Far North And North Regions. The Highest Risk of Stunting Was Among Children Age 36-45 Months (10.2\%, 8.8\%, 11.9\%, And 10.4\% Respectively In the Adamaoua, East, Far North and North Regions). Rural Children across All Four Regions Were More Affected By Stunting (22\%, 27\%, 31.9\%, And 27.4\% Respectively In Adamaoua, East, Far North and North Regions than Their Urban Counterparts (13, 9\%, 8\%, 8\%, And $6.5 \%$ Respectively).

Conclusion: The Study Recorded High Prevalence Of Stunting, Underweight And Wasting Among Children Age 6-59 Months. Malnutrition was noted as a Burden in Children Age 6-59 Months in Cameroon, Particularly the Four Regions of the Study. Age And Place Of Residence Of Child, Were Found To Be Significantly Associated With Stunting And That Child Age Was Significantly Associated With Minimum Acceptable Diet.
\end{abstract}

Keywords: Cameroon, Under-Nutrition, Stunting, Determinants, Association.

\section{Background}

Under nutrition is one of the world's most serious but least addressed health problems (The lancet, 2008). The human and economic costs are enormous, falling hardest on the very poor and on women and children. In developing countries nearly one-third of children are underweight or stunted.

Under nutrition interacts with repeated bouts of infectious disease, causing an estimated 3.5 million preventable maternal and child deaths annually (Bryce et al, 2008) and its economic costs in terms of lost national productivity and economic growth are huge. Children who are undernourished between conception and age two are at high risk for impaired cognitive development, which adversely affects the country's productivity and growth. The economic costs of under nutrition and overweight include direct costs such as the increased burden on the health care system, and indirect costs of lost productivity. Malnutrition is widespread in Cameroon especially in the northern regions of Cameroon and in rural areas. The 2014 multiple indicators cluster survey (MICS) revealed that about $32 \%$ (Estimated 1,163,000 children) of children under the age of five are stunted, 15\% are underweight, and $5 \%$ are wasted. It is estimated that about one-third of stunted children in the CEMAC countries live in Cameroon. Cameroon is among the 36 countries of the world which are most affected by stunting (Lancet series, 2008). Annually Cameroon loses over US $\$ 187$ million in GDP to vitamin and mineral deficiencies (World Bank, 2016, Cameroon, Nutrition at a Glance). The prevalence of stunting imposes significant costs on the Cameroonian economy as well as society. The high mortality due to malnutrition leads to the loss of the economic potential of the child. It affects children in many ways, predisposing them to different infectious diseases, psychosocial mal-development, and cognitive deficiencies.

Factors associated with stunting have been identified elsewhere and include, age, sex, education, household size, lower socioeconomic status, child feeding practices, urban rural residence. Many studies have looked into issues of malnutrition in Cameroon; however, little efforts have been devoted 
to examining the determinants of malnutrition among under-five children. The purpose of this study is to find out magnitude and distribution of stunting in Cameroon, analyse the factors that are directly or indirectly associated with the nutritional status of under-five children in Cameroon, suggest corrective measures which could be intervened in order to uplift current nutritional status, provide necessary information for the policy makers in the field of food and nutrition.

\section{Methods}

\section{Study type and design target population and study samples}

This is a cross-sectional study and relied primarily on data from an extrapolation of secondary data from the Cameroon 2014 MICS survey for explaining possible factors associated with stunting in children below five years of age.

The sample of the multiple indicator cluster survey (MICS) in Cameroon was designed to provide estimates for a large number of indicators on the situation of children and women at the national level for the urban and rural areas. Rural, and for the following 12 geographical areas of study: Adamaoua, Centre (without Yaoundé), Douala, East, Far North, Littoral (without Douala), North, Northwest, West, South, Southwest, Yaoundé.

Urban and rural areas within each area were identified as the main sampling strata. This study used MICS data focusing on four out of the 12 geographical areas which are far north, North, Adamaoua, and East regions.

\section{Sample size and sampling process}

The choice of the sample size of a household survey such as the MICS survey is a compromise between what is required from the sampling accuracy view point and what is feasible from the practical view point including but not limited to budget, field and administrative staff, technical resources, quality control, time constraints, management, sustainability. The larger the sample size, the more precise the survey estimates are and therefore the sampling errors are reduced. However, nonsampling errors generally predominate over sampling errors in large-scale surveys. It is therefore important that the sample size does not exceed the maximum practicable. The Cameroon MICS5 survey targeted a representative sample of 10,746 households. A total of 22 sampling strata were defined using stratified multi-stage cluster sampling approach. The sample was selected in two steps. Within each stratum, a number of census enumeration areas were systematically selected with a probability proportional to size. Following the establishment of a list of households in selected enumeration areas, a systematic sample of 24 urban and 21 rural households was drawn in each sample counting area. The sample was stratified by region, urban and rural and not self-weighted. Weighting was used to ensure the actual representativeness of the sample at the national level and at each region. The actual Sample size used for this study was 3085 children under five distributed into 674, 623, 962 and 825 respectively for the Adamaoua, East, far North and north regions.

\section{Study variables}

Stunting status is established by height-for-age Z-scores (HAZ) indicator using the WHO Growth Standard. Independent household and individual variables was considered at the same level, because, the number of children is lower than households in each strata.

Dependent variables including children characteristics (nutrition) and independent variables; child feeding and caring practices; mother characteristics (literacy, education) and household characteristics (urban/rural, head of household characteristics, were considered.

\section{Data handling and analysis}

The analysis explored bivariate analysis with the under 5 year's old dataset resulting from the children module of the survey. SPSS package 16.0 versions were used to perform the analysis. Linear test were conducted on the data and confirmed the symmetric nature of data followed by bivariate ANOVA test that was used to test for association between stunting and associated factors. 


\section{Results}

\section{Infant and young child feeding practices}

Table 1. Proportion of children with minimum acceptable diet

\begin{tabular}{|c|c|c|c|c|}
\hline & Age & $\%$ MAD & Total & $P$-value $\left(X^{2}\right.$ test $)$ \\
\hline \multirow[t]{3}{*}{ Adamaoua } & $6--11$ & $10.6 \%$ & 60 & \multirow{3}{*}{0.419} \\
\hline & $12--23$ & $22.6 \%$ & 139 & \\
\hline & Total & $33.2 \%$ & 199 & \\
\hline \multirow[t]{3}{*}{ East } & $6--11$ & $5.2 \%$ & 68 & \multirow{3}{*}{0.083} \\
\hline & $12--23$ & $4.7 \%$ & 124 & \\
\hline & Total & $9.9 \%$ & 192 & \\
\hline \multirow[t]{3}{*}{ Far North } & 6--11 & $3.8 \%$ & 116 & \multirow{3}{*}{0.002} \\
\hline & $12--23$ & $13.6 \%$ & 170 & \\
\hline & Total & $17.5 \%$ & 286 & \\
\hline \multirow[t]{3}{*}{ North } & $6--11$ & $4.2 \%$ & 83 & \multirow{3}{*}{0.336} \\
\hline & $12--23$ & $9.7 \%$ & 153 & \\
\hline & Total & $14.0 \%$ & 236 & \\
\hline
\end{tabular}

The table shows global poor feeding practices for children across all four regions with proportion of children having a minimum acceptable diet far below the acceptable threshold of $70 \%$. The situation is worst in the East region followed by the North, then the Far north, ending with Adamaoua with proportions of 9.9\%, 14\%, 17.5\% and 33.2\% respectively. The East and North regions are below national proportion of $16.6 \%$.Also, the results on the table shows that there is no significance difference in feeding practices with the age groups but for the Far North region where the children aged 6-11 months are the most affected.

\section{Nutrition status of children under-five (results extracted from Mics 2014 report)}

Table 2. Nutrition status of children aged 6-59months

\begin{tabular}{|l|l|l|l|l|l|}
\hline $\begin{array}{l}\text { Malnutrition } \\
\text { Index }\end{array}$ & $\begin{array}{l}\text { National } \\
\text { status (\%) }\end{array}$ & $\begin{array}{l}\text { Adamaoua } \\
\text { Region (\%) }\end{array}$ & $\begin{array}{l}\text { East } \\
\text { region } \\
(\%)\end{array}$ & $\begin{array}{l}\text { Far North } \\
\text { region (\%) }\end{array}$ & $\begin{array}{l}\text { North } \\
\text { region (\%) }\end{array}$ \\
\hline Stunting & 31.7 & 37.8 & 35.8 & 41.9 & 33.8 \\
\hline Wasting & 5.2 & 4.0 & 7.8 & 9.0 & 10.1 \\
\hline Underweight & 14.8 & 16.3 & 21.1 & 30.1 & 20.4 \\
\hline
\end{tabular}

The results indicate that stunting was the most common malnutrition problem amongst children under-five in Cameroon and in all four regions of study with prevalence rates of $31.7 \%$ at national level, $37.8 \%, 35.8 \%, 41.9 \%$ and $33.8 \%$ respectively in the Adamaoua, East, Far North and North regions. Stunting levels in all study areas exit the WHO 30\% serious threshold with the Far North region leading with a prevalence rate above the WHO $40 \%$ critical threshold. 
DOI: $10.21522 /$ TIJPH.2013.05.04.Art026

ISSN: $2520-3134$

Determinants of stunting relationship between, child, maternal, economic and residential factors and child stunting.

Adamaoua region

Table 3. Relationship between child's and mothers factors on stunting; adamaoua region

\begin{tabular}{|c|c|c|c|c|c|c|c|c|}
\hline & & \multicolumn{7}{|c|}{ Height-for-age Stunting } \\
\hline & & \multicolumn{5}{|c|}{ percentage below } & \multirow[b]{2}{*}{$\begin{array}{l}\text { P- } \\
\text { value }\end{array}$} & \multirow[b]{2}{*}{$\begin{array}{l}\text { mean } \\
\text { Totale }\end{array}$} \\
\hline & & $-3 \mathrm{SD}$ & $\begin{array}{l}\text { mean } \\
(- \\
\text { 3SD }) \\
\end{array}$ & $\begin{array}{l}P \text { - } \\
\text { value }\end{array}$ & $-2 \mathrm{SD}$ & $\begin{array}{l}\text { mean } \\
(- \\
\text { 2SD }) \\
\end{array}$ & & \\
\hline Sex & boy & $9.2 \%$ & -3.8 & 0.231 & $19.3 \%$ & -3.1 & 0.103 & 1.5 \\
\hline & girl & $6.7 \%$ & -3.7 & & $17.1 \%$ & -3.0 & & 1.7 \\
\hline $\begin{array}{l}\text { Place of } \\
\text { residence }\end{array}$ & Urban & $5.2 \%$ & -3.7 & 0.759 & $13.9 \%$ & -2.9 & 0.091 & 1.4 \\
\hline & Rural & $10.7 \%$ & -3.8 & & $22.4 \%$ & -3.1 & & 1.8 \\
\hline Age & $0-5$ & $1.0 \%$ & -3.8 & 0.017 & $1.8 \%$ & -3.3 & 0.157 & 4.2 \\
\hline & $6--11$ & $0.6 \%$ & -4.6 & & $1.5 \%$ & -3.3 & & 4.2 \\
\hline & $12--23$ & $4.0 \%$ & -3.8 & & $7.7 \%$ & -3.2 & & 1.2 \\
\hline & 24-35 & $3.6 \%$ & -3.8 & & $7.7 \%$ & -3.1 & & -.2 \\
\hline & $36-47$ & $3.9 \%$ & -3.8 & & $10.2 \%$ & -2.9 & & 1.5 \\
\hline & 48-59 & $2.8 \%$ & -3.4 & 0.006 & $7.4 \%$ & -2.9 & & 1.3 \\
\hline $\begin{array}{l}\text { Educational } \\
\text { attainment } \\
\text { of mother }\end{array}$ & None & $8.8 \%$ & -3.8 & 0.885 & $19.3 \%$ & -3.1 & 0.783 & 2.1 \\
\hline & Primary & $5.2 \%$ & -3.8 & & $12.8 \%$ & -3.0 & & 1.2 \\
\hline & Secondary & $1.9 \%$ & -3.7 & & $4.0 \%$ & -3.1 & & .9 \\
\hline & Higher & $0.0 \%$ & & & $0.1 \%$ & -2.4 & & -.6 \\
\hline & $\begin{array}{l}\text { Dont } \\
\text { know/missing }\end{array}$ & $0.0 \%$ & & & $0.1 \%$ & -2.4 & & -2.4 \\
\hline $\begin{array}{l}\text { Quintile of } \\
\text { economic } \\
\text { well-being }\end{array}$ & Very poor & $3.0 \%$ & -3.9 & 0.385 & $4.7 \%$ & -3.4 & 0.052 & 1.1 \\
\hline & Second & $5.6 \%$ & -3.6 & & $12.0 \%$ & -3.0 & & 1.3 \\
\hline & Average & $4.3 \%$ & -3.8 & & $11.1 \%$ & -3.0 & & 2.0 \\
\hline & Quatrième & $2.2 \%$ & -3.9 & & $6.4 \%$ & -2.9 & & 1.9 \\
\hline & Very rich & $0.7 \%$ & -3.6 & & $2.1 \%$ & -2.8 & & .8 \\
\hline
\end{tabular}

A comparison of stunting between males and females showed that slightly more boys are affected than girls. However, there was no significant relationship between sex of child and stunting.

On the age of child, a significant relationship exists between the age of the child and severe stunting $(\mathrm{p}=0.017)$. Children below the eleven months were less stunted than those between that ages of 12 to 59 months. Results Also indicate that there were more stunted children I rural areas than in urban areas. However there exist no significant relationship between child's residence area and child's stunting

Regarding mother's level of education, results indicate mothers who have never attended school have the highest number of stunted children, followed by those with primary level and hen those with 
secondary education. Again, bivariate analysis reveals there is no significant relationship between mother's level of education and child's stunting.

On the economic well-being of family, results indicate that children from second level as well as average homes were more affected by stunting whereas those from very poor and very rich homes were less affected by stunting. However, there was no significant relationship between family's economic well-being and child's stunting.

\section{East region}

Table 4. Relationship between child, Mothers factors and child's stunting

\begin{tabular}{|c|c|c|c|c|c|c|c|c|}
\hline & & \multicolumn{7}{|c|}{ Height-for-age Stunting } \\
\hline & & \multicolumn{5}{|c|}{ percentage below } & \multirow[b]{2}{*}{$\begin{array}{l}P \text { - } \\
\text { value }\end{array}$} & \multirow[b]{2}{*}{$\begin{array}{l}\text { mean } \\
\text { Total }\end{array}$} \\
\hline & & $-3 \mathrm{SD}$ & $\begin{array}{l}\text { mean } \\
(- \\
\text { 3SD })\end{array}$ & $\begin{array}{l}P \text { - } \\
\text { value }\end{array}$ & $-2 \mathrm{SD}$ & $\begin{array}{l}\text { mean } \\
(- \\
2 \mathrm{SD}) \\
\end{array}$ & & \\
\hline \multirow[t]{2}{*}{ Sex } & boy & $8.2 \%$ & -3.9 & 0.100 & $19.1 \%$ & -3.1 & 0.352 & 7.1 \\
\hline & girl & $6.6 \%$ & -3.6 & & $15.9 \%$ & -3.0 & & 5.9 \\
\hline \multirow[t]{2}{*}{$\begin{array}{l}\text { Place of } \\
\text { residence }\end{array}$} & $\begin{array}{l}\text { Urba } \\
\text { n }\end{array}$ & $3.2 \%$ & -3.8 & 0.991 & $8.0 \%$ & -3.0 & 0.539 & 9.1 \\
\hline & Rural & $11.6 \%$ & -3.8 & & $27.0 \%$ & -3.0 & & 4.9 \\
\hline \multirow[t]{6}{*}{ Age } & $0-5$ & $0.5 \%$ & -4.8 & 0.038 & $0.8 \%$ & -3.7 & 0.494 & 1.0 \\
\hline & 6--11 & $0.5 \%$ & -3.6 & & $1.4 \%$ & -2.8 & & 7.0 \\
\hline & $\begin{array}{l}12-- \\
23\end{array}$ & $4.5 \%$ & -3.5 & 0.030 & $8.8 \%$ & -3.0 & & 3.2 \\
\hline & 24-35 & $3.4 \%$ & -3.9 & & $8.2 \%$ & -3.1 & & 8.5 \\
\hline & $36-47$ & $3.4 \%$ & -3.9 & & $8.8 \%$ & -3.0 & & 7.9 \\
\hline & 48-59 & $2.6 \%$ & -3.7 & & $6.9 \%$ & -3.0 & & 9.1 \\
\hline \multirow[t]{5}{*}{$\begin{array}{l}\text { Educational } \\
\text { attainment } \\
\text { of mother }\end{array}$} & None & $5.1 \%$ & -3.8 & 0.849 & $11.7 \%$ & -3.0 & 0.820 & 1.7 \\
\hline & $\begin{array}{l}\text { Prim } \\
\text { ary } \\
\end{array}$ & $7.1 \%$ & -3.7 & & $16.7 \%$ & -3.0 & & 10.6 \\
\hline & $\begin{array}{l}\begin{array}{l}\text { Secon } \\
\text { dary }\end{array} \\
\end{array}$ & $2.6 \%$ & -3.8 & & $6.4 \%$ & -3.0 & & 3.7 \\
\hline & $\begin{array}{l}\text { High } \\
\text { er }\end{array}$ & $0.0 \%$ & & & $0.2 \%$ & -2.4 & & .1 \\
\hline & $\begin{array}{l}\text { Dont } \\
\text { know } \\
\text { /missi } \\
\text { ng } \\
\end{array}$ & $0.0 \%$ & & & & & & \\
\hline \multirow[t]{4}{*}{$\begin{array}{l}\text { Quintile of } \\
\text { economic } \\
\text { well-being }\end{array}$} & $\begin{array}{l}\text { Very } \\
\text { poor }\end{array}$ & $3.0 \%$ & -3.7 & 0.439 & $7.1 \%$ & -3.0 & 0.302 & 3.9 \\
\hline & $\begin{array}{l}\text { Secon } \\
\text { d }\end{array}$ & $7.9 \%$ & -3.7 & & $17.0 \%$ & -3.1 & & 8.0 \\
\hline & $\begin{array}{l}\text { Aver } \\
\text { age }\end{array}$ & $2.6 \%$ & -4.0 & & $6.7 \%$ & -3.1 & & 6.6 \\
\hline & Quat & $1.1 \%$ & -3.6 & & $3.7 \%$ & -2.7 & & 5.9 \\
\hline
\end{tabular}


DOI: $10.21522 /$ TIJPH.2013.05.04.Art026

ISSN: $2520-3134$

\begin{tabular}{|l|l|l|l|l|l|l|l|l|}
\hline & rième & & & & & & & \\
\hline & $\begin{array}{l}\text { Very } \\
\text { rich }\end{array}$ & $0.2 \%$ & -3.3 & & $0.5 \%$ & -2.7 & & 3.8 \\
\hline
\end{tabular}

A comparison of stunting between males and females showed that slightly more boys are affected than girls. However, there was no significant relationship between sex of child and stunting.

On the age of child, a significant relationship exists between the age of the child and severe stunting ( $p=0.038$ ). Children below the eleven months were less stunted than those between that ages of 12 to 59 months. Children aged 12-23 are the most affected by stunting.

Results Also indicate that there were more stunted children I rural areas than in urban areas. However there exist no significant relationship between child's residence area and child's stunting

Regarding Mother's level of education, results indicate mothers who have never attended school have the highest number of stunted children, followed by those with primary level and hen those with secondary education. Again, bivariate analysis reveals there is no significant relationship between mother's level of education and child's stunting.

On the economic well-being of family, results indicate that children from second level as well as average homes were more affected by stunting whereas those from very poor and very rich homes were less affected by stunting. However, there was no significant relationship between family's economic well-being and child's stunting

\section{Far north region}

Table 5. Relationship between child's factors, mother' factors, economic and residential factors on child's stunting far north region

\begin{tabular}{|c|c|c|c|c|c|c|c|c|}
\hline & & \multicolumn{7}{|c|}{ Height-for-age Stunting } \\
\hline & & \multicolumn{5}{|c|}{ percentage below } & \multirow[b]{2}{*}{$\begin{array}{l}P \text { - } \\
\text { value }\end{array}$} & \multirow[b]{2}{*}{$\begin{array}{l}\text { mean } \\
\text { Total }\end{array}$} \\
\hline & & $-3 \mathrm{SD}$ & $\begin{array}{l}\text { mean } \\
(- \\
\text { 3SD }) \\
\end{array}$ & $\begin{array}{l}P \text { - } \\
\text { value }\end{array}$ & $-2 \mathrm{SD}$ & $\begin{array}{l}\text { mean } \\
(- \\
\text { 2SD }) \\
\end{array}$ & & \\
\hline \multirow[t]{2}{*}{ Sex } & boy & $8.2 \%$ & -3.9 & 0.100 & $19.1 \%$ & -3.1 & 0.352 & 7.1 \\
\hline & girl & $6.6 \%$ & -3.6 & & $15.9 \%$ & -3.0 & & 5.9 \\
\hline \multirow[t]{2}{*}{$\begin{array}{l}\text { Place of } \\
\text { residence }\end{array}$} & $\begin{array}{l}\text { Urba } \\
\mathbf{n}\end{array}$ & $3.2 \%$ & -3.8 & 0.991 & $8.0 \%$ & -3.0 & 0.539 & 9.1 \\
\hline & $\begin{array}{l}\text { Rura } \\
1\end{array}$ & $11.6 \%$ & -3.8 & & $27.0 \%$ & -3.0 & & 4.9 \\
\hline \multirow[t]{6}{*}{ Age } & $0-5$ & $0.5 \%$ & -4.8 & 0.038 & $0.8 \%$ & -3.7 & 0.494 & 1.0 \\
\hline & 6--11 & $0.5 \%$ & -3.6 & & $1.4 \%$ & -2.8 & & 7.0 \\
\hline & $\begin{array}{l}12-- \\
23\end{array}$ & $4.5 \%$ & -3.5 & 0.030 & $8.8 \%$ & -3.0 & & 3.2 \\
\hline & $\begin{array}{l}24- \\
35\end{array}$ & $3.4 \%$ & -3.9 & & $8.2 \%$ & -3.1 & & 8.5 \\
\hline & $\begin{array}{l}36- \\
47 \\
\end{array}$ & $3.4 \%$ & -3.9 & & $8.8 \%$ & -3.0 & & 7.9 \\
\hline & $\begin{array}{l}48- \\
59\end{array}$ & $2.6 \%$ & -3.7 & & $6.9 \%$ & -3.0 & & 9.1 \\
\hline $\begin{array}{l}\text { Educational } \\
\text { attainment of } \\
\text { mother }\end{array}$ & None & $5.1 \%$ & -3.8 & 0.849 & $11.7 \%$ & -3.0 & 0.820 & 1.7 \\
\hline & $\begin{array}{l}\text { Prim } \\
\text { ary }\end{array}$ & $7.1 \%$ & -3.7 & & $16.7 \%$ & -3.0 & & 10.6 \\
\hline
\end{tabular}




\begin{tabular}{|l|l|l|l|l|l|l|l|l|}
\hline & $\begin{array}{l}\text { Seco } \\
\text { ndar } \\
\text { y }\end{array}$ & $2.6 \%$ & -3.8 & & $6.4 \%$ & -3.0 & & 3.7 \\
\hline & $\begin{array}{l}\text { High } \\
\text { er }\end{array}$ & $0.0 \%$ & & & $0.2 \%$ & -2.4 & & .1 \\
\hline & $\begin{array}{l}\text { Dont } \\
\text { kno } \\
\text { w/mi } \\
\text { ssing }\end{array}$ & $0.0 \%$ & & & & & & \\
\hline & & & & & & & & \\
\hline $\begin{array}{l}\text { Quintile of } \\
\text { economic } \\
\text { well-being }\end{array}$ & $\begin{array}{l}\text { Very } \\
\text { poor }\end{array}$ & $3.0 \%$ & -3.7 & 0.439 & $7.1 \%$ & -3.0 & 0.302 & 3.9 \\
\hline & $\begin{array}{l}\text { Seco } \\
\text { nd }\end{array}$ & $7.9 \%$ & -3.7 & & $17.0 \%$ & -3.1 & & 8.0 \\
\hline & $\begin{array}{l}\text { Aver } \\
\text { age }\end{array}$ & $2.6 \%$ & -4.0 & & $6.7 \%$ & -3.1 & & 6.6 \\
\hline & $\begin{array}{l}\text { Quat } \\
\text { rièm } \\
\text { e }\end{array}$ & $1.1 \%$ & -3.6 & & $3.7 \%$ & -2.7 & & 5.9 \\
\hline $\begin{array}{l}\text { Very } \\
\text { rich }\end{array}$ & $0.2 \%$ & -3.3 & & $0.5 \%$ & -2.7 & & 3.8 \\
\hline
\end{tabular}

A comparison of stunting between males and females showed that slightly more boys are affected than girls. However, there was no significant relationship between sex of child and stunting.

On the age of child, a significant relationship exists between the age of the child and stunting $(\boldsymbol{p}=\mathbf{0 . 0 3 4})$. Children aged 36-47 months are the most affected by stunting.

Results Also indicate that there were more stunted children in rural areas than in urban areas and that there exists a significant relationship between child's residence area and child's stunting $(\boldsymbol{p}=\mathbf{0 . 0 4 5})$

Regarding mother's level of education, results indicate mothers who have never attended school have the highest number of stunted children, followed by those with primary level and then those with secondary education. Again, bivariate analysis reveals there is no significant relationship between mother's level of education and child's stunting.

On the economic well-being of family, results indicate the poorer the family the more stunted is the children. More stunted children were found in very poor homes followed by second level homes then average homes and lastly in very rich homes. However, there was no significant relationship between family's economic well-being and child's stunting

\section{North region}

Table 6. Relationship between, child, maternal, economic and residential factors and child stunting in north region

\begin{tabular}{|c|c|c|c|c|c|c|c|c|}
\hline & & \multicolumn{7}{|c|}{ Height-fo-age Stunting } \\
\hline & & \multicolumn{5}{|c|}{ percentage below } & \multirow[b]{2}{*}{$\begin{array}{l}\mathrm{P}- \\
\text { value }\end{array}$} & \multirow[b]{2}{*}{$\begin{array}{l}\text { mean } \\
\text { Total }\end{array}$} \\
\hline & & $-3 \mathrm{SD}$ & $\begin{array}{l}\text { mean (- } \\
3 \mathrm{SD})\end{array}$ & $\begin{array}{l}\mathrm{P}- \\
\text { value }\end{array}$ & $-2 \mathrm{SD}$ & $\begin{array}{l}\text { mean } \\
(- \\
2 \mathrm{SD})\end{array}$ & & \\
\hline \multirow[t]{2}{*}{ Sex } & Boy & $7.0 \%$ & -4.0 & 0.231 & $19.0 \%$ & -3.0 & 0.246 & 0.50 \\
\hline & Girl & $6.1 \%$ & -3.7 & & $14.9 \%$ & -2.9 & & 1.55 \\
\hline \multirow[t]{2}{*}{ Place of residence } & Urban & $2.1 \%$ & -3.8 & 0.821 & $6.5 \%$ & -2.9 & 0.648 & 1.43 \\
\hline & Rural & $11.0 \%$ & -3.9 & & $27.4 \%$ & -3.0 & & 0.87 \\
\hline & & & & & & & & \\
\hline
\end{tabular}


DOI: $10.21522 /$ TIJPH.2013.05.04.Art026

ISSN: $2520-3134$

\begin{tabular}{|l|l|l|l|l|l|l|l|l|}
\hline Age & $0-5$ & $0.7 \%$ & -3.9 & 0.017 & $1.6 \%$ & -3.2 & 0.296 & -0.38 \\
\hline & $6-11$ & $0.2 \%$ & -3.2 & & $1.3 \%$ & -2.5 & & 3.04 \\
\hline & $12--23$ & $3.2 \%$ & -4.0 & & $7.5 \%$ & -3.1 & & -0.22 \\
\hline & $24-35$ & $3.2 \%$ & -3.8 & & $7.2 \%$ & -3.0 & & 0.49 \\
\hline & $36-47$ & $3.5 \%$ & -3.9 & & $10.4 \%$ & -2.9 & & 2.10 \\
\hline & $48-59$ & $2.3 \%$ & -3.8 & 0.006 & $5.9 \%$ & -2.9 & & 1.13 \\
\hline & & & & & & & & \\
\hline $\begin{array}{l}\text { Educational } \\
\text { attainment of } \\
\text { mother }\end{array}$ & None & $9.0 \%$ & -3.9 & 0.457 & $21.7 \%$ & -3.0 & 0.161 & 1.16 \\
\hline & Primary & $3.5 \%$ & -3.8 & & $10.7 \%$ & -2.8 & & 1.10 \\
\hline & Secondary & $0.6 \%$ & -4.3 & & $1.6 \%$ & -3.2 & & -1.34 \\
\hline & Higher & $0.0 \%$ & & & $0.0 \%$ & & & 0.14 \\
\hline $\begin{array}{l}\text { Quintile of } \\
\text { economic well- } \\
\text { being }\end{array}$ & Very poor & $8.7 \%$ & -3.8 & 0.715 & $19.2 \%$ & -3.0 & 0.416 & 0.99 \\
\hline & Second & $2.9 \%$ & -4.0 & & $9.2 \%$ & -3.0 & & 0.48 \\
\hline & Average & $0.6 \%$ & -3.6 & & $2.7 \%$ & -2.7 & & 0.15 \\
\hline & Quadrium & $0.6 \%$ & -4.0 & & $1.9 \%$ & -2.9 & & 1.93 \\
\hline & Very rich & $0.2 \%$ & -4.1 & & $1.0 \%$ & -2.8 & & 6.68 \\
\hline
\end{tabular}

A comparison of stunting between males and females showed that more boys are affected than girls. However, there was no significant relationship between sex of child and stunting.

On the age of child, a significant relationship exists between the age of the child and stunting ( $\mathbf{p = 0 . 0 1 7 )}$. Children aged 48-59 months are the most affected by stunting $(\mathrm{p}=0.006)$.

Results Also indicate that there were more stunted children I rural areas than in urban areas. However there exist no significant relationship between child's residence area and child's stunting

Regarding mother's level of education, results indicate mothers who have never attended school have the highest number of stunted children, followed by those with primary level and then those with secondary education. Again, bivariate analysis reveals there is no significant relationship between mother's level of education and child's stunting.

On the economic well-being of family, results indicate the poorer the family the more stunted are the children. More stunted children were found in very poor homes followed by second level homes then average homes and lastly in very rich homes. However, there was no significant relationship between family's economic well-being and child's stunting.

\section{Discussion}

\section{Infant and young child feeding practices}

The study reveals global poor feeding practices for children across all four regions with proportion of children having a minimum acceptable diet far below the acceptable threshold of $70 \%$. The situation is worst in the East region followed by the North, then the Far north, ending with Adamaoua with proportions of $9.9 \%, 14 \%, 17.5 \%$ and $33.2 \%$ respectively. The East and North regions are below national proportion of $16.6 \%$. The results also show that across all four regions of study MAD increases with age with children aged 6-11 months being the most affected by poor feeding practices. These results confirm distributions of MAD within age groups at national level as revealed by MICS5 Survey of 2014 However statistical analysis did not show this difference between age group and feeding practices except for the Far North region where the children aged 6-11 months are the most affected $(p=0.002)$.. The poor feeding and consequent low proportion of children with minimum acceptable diet could be linked to factors such as lack of knowledge, influence of culture custodians, limited availability and access of households to complementary food, patterns and burden of work and other responsibilities and limited involvement of men to the day-to-day care of the child as revealed by 
a study conducted in Rwanda as being main barriers affecting the use of appropriate infant and young child-feeding practices (Joyse Nankumbi et al 2015).

\section{Prevalence of stunting, wasting and underweight}

In Cameroon as well as to the study areas and other countries, malnutrition among children is a major public health problem. The findings of this study revealed that almost one-third of children 6-59 months in Cameroon and in all four regions of study are affected by stunting. The prevalence of stunting was found to be $31.7 \%$ at national level, $37.8 \%, 35.8 \%, 41.9 \%$ and $33.8 \%$ respectively in the Adamaoua, East, Far North and North regions. Stunting levels in all study areas exit the WHO 30\% serious threshold with the Far North region leading with a prevalence rate above the WHO $40 \%$ critical threshold.

Wasting also was proven by the study to be a public health problem In the East, Far north and north regions with respective prevalence's of $7.8 \%, 9.0 \%$ and $10.1 \%$ all situated in the WHO poor nutrition situation thresholds. With regards to underweight, the Adamaoua regions with a prevalence rate of $16.3 \%$ has a serious malnutrition problem while the East, Far North and North regions with prevalence rates of $21.1 \%, 30.1 \%$ and $20.4 \%$ respectively present a critical malnutrition situation with regards to WHO classification

\section{Associated factors for stunting}

When we compared the present finding to the cut off point for public health significant, which is $>30 \%$ for stunting, it is too high which needs the attention of all concerned bodies.

Sex and age of children were important demographic variables and were the primary basis of demographic classification in this study. The risk of malnutrition increases with age across all four regions. The highest risk of stunting was among children age 36-45 months $(10.2 \%, 8.8 \%, 11.9 \%$, and $10.4 \%$ respectively in the Adamaoua, East, Far North and North regions) followed by children aged 12-23month, while children aged 0-5 months and 6-11 months were the least affected by stunting. This finding was consistent with other studies done in Rural Rwanda, which shows that the main contributing factors for under-five stunting were found age of the child (Joyce et al 2015).

Finding from Ethiopia also shows, the prevalence of stunting among children age 6-59 months was about 47\%, and the prevalence increased with age through 36-47 months (58\%) (Yalew BM, Amsalu F, Bikes D (2014).

In the current study the high rates of stunting observed after 12 months might be linked to inappropriate complementary feeding during the weaning period to stopping breastfeeding earlier than the suggested 24 months. This low risk at 0-5months and 6-11months might be due to the protective effect of breastfeeding, since almost all children, $96.3 \%$ in the study area were breastfed and most of them continue to be breastfed throughout the first year of their life.

The results of the present study revealed a higher prevalence of stunting in boys $(19.3 \%, 19.2 \%$, $21.0 \%$, and $19.4 \%$ respectively in the Adamaoua, East, Far North and North regions respectively) than girls $(17.1 \%, 15.9 \%, 18.9 \%$, and $14.9 \%$ respectively). However, statistical analysis did not confirm this association between stunting and child sex. These were similar to the results at national level (MICS5 2014) and inverse to other studies were statistical analysis confirmed the association between sex of child and stunting like in done in Ethiopia, findings from West Gojam shows that male children were statistically about 1.5 times more likely to be stunted than female children [Beka T, Wambui K, Zewditu G, Girum T (2009). A study done in South Africa has shown that male preschoolers were at higher risk of being stunted than their female counterparts (Lesiapeto MS 2010).

Regarding the economic well-being of family, results of the present study indicate across three of the four regions of study (East, Far north, and North region) Children from household with the lowest economic quintile are more likely to be stunted while those from household with highest economic quintile are less likely to be stunted. However, there was no significant relationship between family's economic well-being and child's stunting.

Rural children across all four regions were more affected by stunting $(22 \%, 27 \%, 31.9 \%$, and $27.4 \%$ respectively in the Adamaoua, East, Far north and North regions than their urban counterparts $(13,9 \%, 8 \%, 8 \%$, and $6.5 \%$ respectively). This difference was only statistically proven to be true for the Far north region $(\boldsymbol{p}=\mathbf{0 . 0 3 4})$. 
DOI: $10.21522 /$ TIJPH.2013.05.04.Art026

ISSN: $2520-3134$

This results are consistent with those of another studies such as that conducted in Pakistan children where stunting significantly affected rural children (17\%) than their urban counterparts $10 \%$, $(\boldsymbol{p}=\mathbf{0 . 0 0 1})$ (Muhamad .U.M 2011).

In all four regions, stunting amongst children with illiterate mothers was higher as compared to children having mothers with higher education. However this result were not proven to be statistically significant contrary to other studies conducted in Uganda which revealed that parental education was a predictor of under nutrition in children (Kika Funda, 1998)

\title{
Conclusion
}

The research was a secondary data analysis of data extracted from national MICS survey conducted in Cameroon in 2014. The purpose of the study was to identify and determine the factors associated with stunting in the Adamaoua, East, and Far North and North regions of Cameroon. The result of this study revealed that the prevalence of stunting, underweight and wasting among children age 6-59 months was high. Malnutrition continued to be a substantial burden in children age 6-59 months in Cameroon and in particular the four regions of study (Adamaoua, East, Far North and North regions).Following bivariate statistical analysis, age and place of residence of child, were found to be significantly associated with Stunting and that child age was significantly associated with minimum acceptable diet.

\author{
Abbreviations \\ CEMAC Economic and Monetary Committee of Central Africa \\ DHS Demographic and Health Surveys \\ GDP Growth and Development Product \\ MICS Multiple Indicators Cluster Survey \\ SUN Scaling Up nutrition \\ UNICEF United Nation Children Funds \\ UNSCN United Nation Standing Committee for Nutrition \\ WASH Water Hygiene and Sanitation
}

\section{References}

[1].Abuya BA1, Ciera J, Kimani-Murage E (2012). Effect of mother's education on child's nutritional status in the slums of Nairobi. BMC Pediatr 12: 80.

[2].Addis Continental Institute of Public Health December 04, 2009.

[3].Ahmed E, Mofida Y, Elkhalifa, Maria H, ElnasikH (2011). Nutritional status of the children under age of five in a desertified area of Sudan; alrawakeeb valley, Khartoum, Sudan. International Journal of Current Research 2: 103-108.

[4].Ahmed S, Ferdous F, Das J, Farzana FD, Chisti M.J (2015). Shigellosis among Breastfed Children: A Facility Based Observational Study in Rural Bangladesh. J Gastrointest Dig Syst 5:327. doi:10.4172/2161069X.1000327.

[5].Babasaheb A. (2011). An Investigation into Factors Affecting Child Undernutrition in Madhya Pradesh Sibabrata Das and Harihar Sahoo. Ravenshaw University, Cuttack 753 003, Odisha, India harashtra. 2011: 6-7.

[6].Beka T, Wambui K, Zewditu G, Girum T (2009). Magnitude and determinants of stunting in children underfive years of age in food surplus region of Ethiopia: The case of West Gojam Zone. Ethiop. J. Health Development 23: 98-106.

[7].Bryce, J. (2008). Maternal and child under utrition.

[8].Gobotswang K. (2008). Factors associated with nutritional status of the under five children Amita Pradhana. Asian journal of medical sciences. 2008.

[9].Kandala NB1, Madungu TP, Emina JB, Nzita KP, Cappuccio FP (2011). Malnutrition among children under the age of five in the Democratic Republic of Congo (DRC): does geographic location matter? BMC Public Health 11: 261.

[10]. Laure NJ, Christelle MM, Bilkha L, Desire MH, Julius O (2014). Nutritional Status and Risk Factors of Malnutrition among 0-24 Months Old Children Living in Mezam Division, North West Region, Cameroon. J Nutr Disorders Ther 4:150. doi:10.4172/2161-0509.1000150.

[11]. Mostafa KS (2011). Socio-economic determinants of severe and moderate stunting among under-five children of rural Bangladesh. Malays J Nutr 17: 105-118 
[12]. Nagahori C (1), Tchuani JP, Yamauchi T (2015). Factors associated with nutritional status in children aged 5-24 months in the Republic of Cameroon: Laure NJ, Christelle MM, Bilkha L, Desire MH, Julius O (2014) Nutritional Status and Risk Factors of Malnutrition among 0-24 Months Old Children Living in Mezam Division, North West Region, Cameroon. J Nutr Disorders Ther 4:150. doi:10.4172/2161-0509.1000150.

[13]. Nakamori M, Ninh N.X, Khan N.C, Huong C.T, Tuan N.A, Mai L.B. (2010). Nutritional status, feeding practice and incidence of infectious diseases among children aged 6 to 18 months in northern mountainous Vietnam.

[14]. Ngambouk Vitalis Pemunta and Mathias Alubafi Fubah (2014). Socio-cultural determinants of infant malnutrition in cameroon. Journal of Biosocial Science, Available on CJO 2014 doi: $10.1017 /$ S0021932014000145.

[15]. Nguyen NH, Nguyen NH2 (2009). Nutritional Status and Determinants of Malnutrition in Children Under Three Years of Age in Nghean, Vietnam. Pakistan Journal of Nutrition. 8: 958-964.

[16]. Paramita S, Nina P, Benjamin A. I. (2010). Epidemiological correlates of under-nutrition in under-5 years children in an urban slum of Ludhiana, india Health and Population: Perspectives and Issues 33: 1-9.

[17]. Report of a webcast colloquium on the operational issues around setting and implementing national stunting reduction agendas Childhood Stunting: Challenges and Opportunities 14 October 2013 - WHO Geneva. [18]. Scaling up Nutrition a Framework for Action, the Lancet, and "Maternal and Child Under nutrition," Special Series. January, 2008: 2-10.

[19]. Sumit M (2010). Assessing Vulnerability to Chronic Undernutrition among Under-Five Children in Egypt. Academic Editor: Abbas Bhuiya10-12.

[20]. Tibilla M.A (2007). The nutritional impact of the world food programme-supported supplementary feeding programme on children less than five years in rural tamale, Ghana 17-18.

[21]. The Lancet 2008.

[22]. United Nation System Standing Committee On Nutrition. Report On The World Nutrition Situation, 2010.

[23]. USAID, save the children: factors associated with stunting in Ethiopian children under five.

[24]. Yalew BM, Amsalu F, Bikes D (2014). Prevalence and Factors Associated with Stunting, Underweight and Wasting: A Community Based Cross Sectional Study among Children Age 6-59 Months at Lalibela Town, Northern Ethiopia. J Nutr Disorders Ther 4:147. doi:10.4172/2161-0509.1000147.

[25]. Zhang XS, Pebody RG, McCauley JW (2016). Seasonal Influenza Vaccination: Its Expected and Unexpected Effects. J Vaccines Vaccin 7:314. doi:10.4172/2157-7560.1000314. 